\title{
Risk factors for degenerative spondylolisthesis: a systematic review
}

Authors John G DeVine1, Jeannette M Schenk-Kisser², Andrea C Skelly²

Institutions ${ }^{1}$ Dwight D. Eisenhower Army Medical Center Fort Gordon, GA, USA

${ }^{2}$ Spectrum Research Inc, Tacoma, WA, USA

\section{ABSTRACT}

Study design: Systematic literature review.

Rationale: Many authors have postulated on various risk factors associated with the pathogenesis of degenerative spondylolisthesis (DS), yet controversies regarding those risk factors still exist.

Objective: To critically appraise and summarize evidence on risk factors for DS.

Methods: Articles published before October 15, 2011, were systematically reviewed using PubMed and bibliographies of key articles. Each article was subject to quality rating and was analyzed by two independent reviewers.

Results: From 382 citations, 30 underwent full-text review. Fourteen studies met inclusion criteria. All but two were considered poor quality. Female gender and higher facet joint angle were consistently associated with an increased risk of DS across multiple studies. Multiple studies also consistently reported no association between back pain and prolonged occupational sitting. Associations between age, parity, lumbosacral angle, lumbar lordosis, facet joint tropism, and pelvic inclination angles were inconsistent.

Conclusions: There appears to be consistent evidence to suggest that the risk of DS increases with increasing age and is greater for females and people with a greater facet joint angle. 


\section{STUDY RATIONALE AND CONTEXT}

Spondylolisthesis with an intact vertebral arch and associated advanced arthritic changes in the facet joints at the level of vertebral displacement is termed degenerative spondylisthesis (DS). The displacement most commonly occurs at the L4/L5 level and rarely exceeds $30 \%$ of the width of the adjacent vertebral body. Degenerative spondylisthesis has been the subject of numerous studies since first described by Junghanns in 1930 [1]. Many authors have postulated on various risk factors associated with the pathogenesis of DS, yet controversies regarding those risk factors and the etiology of DS still exist.

\section{OBJECTIVE}

To critically appraise and summarize evidence on risk factors for DS.
Fig 1 Results of literature search.

\section{Total citations from search} $(n=382)$

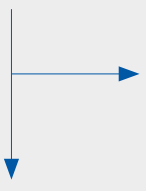

3. Retrieved for full-text evaluation $(n=30)$

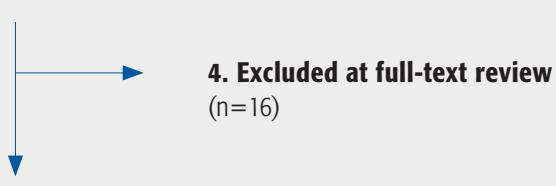

5. Publications included $(n=14)$

\section{MATERIALS AND METHODS}

Study design: Systematic review.

Search: PubMed and bibliographies of key articles (Fig 1).

Dates searched: The search was conducted through October 15, 2011; no time limits were placed on the search.

Inclusion criteria: Articles addressing the prognostic factors for lumbar degenerative spondylolisthesis (Table 1).

Exclusion criteria: Studies of patients with isthmic spondylolisthesis, fractures of the lumbar spine, tumor, or iatrogenic spondylolisthesis were excluded.

\section{Prognostic factors:}

- Sociodemographic/patient characteristics (age, gender, race, BMI, pregnancy status/history)

- Activity/work (occupational exposures, sport)

- Radiographic measures (disc height, lordosis/angles)

- Anatomical characteristics (lumbar facet morphology)

Analysis: Descriptive.

Details about methods can be found in the electronic supplemental material at $w w w$.aospine.org/ebsj

\section{RESULTS}

- From 382 citations, 30 underwent full-text review. Fourteen studies met the inclusion criteria for assessing risk factors associated with DS. All studies were cross-sectional; most of which (12) were considered poor quality, only two were considered good quality (CoE II), and only three considered confounding factors. Web Appendix Section 4a provides the critical appraisal for these 14 studies, and Web Appendix Section 6 describes the reasons for excluding studies.

\section{Common prognostic factors evaluated in multiple studies}

- Evidence across five studies reporting on the association between age and risk of DS is inconclusive, but studies that controlled for confounding suggest the risk of DS increases with increasing age (Table 2). 
Table 1 Characteristics of included studies.*

\begin{tabular}{|c|c|c|c|}
\hline Author & Demographics ${ }^{\dagger}$ & Inclusion criteria & Exclusion criteria \\
\hline $\begin{array}{l}\text { Chen and } \\
\text { Wei [13] } \\
(2009)\end{array}$ & $\begin{array}{l}\mathrm{N}=132 \\
\text { Female: } 100 \% \\
\text { Age, mean } \pm \text { SD: } \\
\text { - DS: } 55.36 \pm 5.61 \text { y } \\
\text { - Control: } 54.90 \pm 5.52 \text { y }\end{array}$ & $\begin{array}{l}\text { General: } \\
\text { - All subjects were recruited from a Taiwanese hospital between } \\
\text { January and December } 2004 \\
\text { Cases: } \\
\text { - Radiographically confirmed lumbar spondylolisthesis } \\
\text { - Visiting rehabilitation/orthopaedic outpatient deptartment } \\
\text { because of low back pain } \\
\text { - Female } \\
\text { - } 45-64 \text { y } \\
\text { - First-time diagnosis of lumbar spondylolisthesis } \\
\text { Control: } \\
\text { - No spondylolisthesis } \\
\text { - Age- and gender-matched to cases }\end{array}$ & $\begin{array}{l}\text { - Missing or inadequate films } \\
\text { - Combined with lumbar retrolisthesis } \\
\text { - Posttraumatic lumbar spondylolisthesis } \\
\text { - Received further surgical treatment }\end{array}$ \\
\hline $\begin{array}{l}\text { Horikawa et } \\
\text { al [5] } \\
(2006)\end{array}$ & $\begin{array}{l}\mathrm{N}=528 \\
\text { Female: } 61.2 \% \\
\text { Age, mean: } 70.6 \text { (range, 65-92) y }\end{array}$ & $\begin{array}{l}\text { General } \\
-\geq 65 \text { y } \\
\text { - Residing in a fishing/farming village located in Nansei-cho, Mie } \\
\text { prefecture, Japan }\end{array}$ & None reported \\
\hline $\begin{array}{l}\text { Sanderson } \\
\text { and Fraser } \\
{[6](1996)}\end{array}$ & $\begin{array}{l}N=1069 \\
\text { Female: } 88.8 \% \\
\text { Age, mean } \pm S D \text { : } \\
\text { - Men: } 64.1 \pm 5.8 \mathrm{y} \\
\text { - Parous women: } 63.1 \pm 5.1 \mathrm{y} \\
\text { - Nulliparous women: } 61.2 \pm 6.4 \mathrm{y}\end{array}$ & $\begin{array}{l}\text { General } \\
\text { - Low back pain } \\
\text { - Patients who attended a spinal surgeon's practice from } \\
\text { 1990-1995 }\end{array}$ & $\begin{array}{l}\text { - Isthmic spondylolysis } \\
\text { - Previous lumbar surgery }\end{array}$ \\
\hline $\begin{array}{l}\text { Mariconda } \\
\text { et al [2] } \\
(2007)\end{array}$ & $\begin{array}{l}\mathrm{N}=120 \\
\text { Female: } 52 \% \\
\text { Age, mean } \pm \text { SD: } 57.5 \pm 11.8 \mathrm{y}\end{array}$ & $\begin{array}{l}\text { General } \\
\text { - Patients attending outpatient clinic at either of two Italian } \\
\text { hospitals } \\
\text { - >l-year low back pain (radiating or not) } \\
\text { - Willing to undergo MRI } \\
\text { - Speak Italian }\end{array}$ & $\begin{array}{l}\text { - }<40 \text { y } \\
\text { - Secondary causes of LBP (tumor, } \\
\text { infection, congenital anomaly, trauma, } \\
\text { psoriasis, chronic polyarthritis, } \\
\text { osteoporosis) } \\
\text { - Previous back surgery }\end{array}$ \\
\hline $\begin{array}{l}\text { Hosoe and } \\
\text { Ohmori [4] } \\
(2008)\end{array}$ & $\begin{array}{l}\mathrm{N}=250 \\
\text { Female: } 47.2 \% \\
\text { Age, mean: } \\
\text { - DS: } 68.2 \text { (range, 42-93) y } \\
\text { - Control: } 46.8 \text { (range, 21-69) y }\end{array}$ & $\begin{array}{l}\text { General } \\
\text { - Patients who had spinal x-rays taken at Nagoya Daini Red Cross } \\
\text { Hospital between } 1983 \text { and } 1998 \\
\text { DS: } \\
\text { - Patients with DS of the } 5 \text { th vertebra } \\
\text { Control: } \\
\text { - Random sample of } 293 \text { with normal (apart from age-related } \\
\text { changes) on x-rays }\end{array}$ & $\begin{array}{l}\text { - Vertebral slip }<5 \% \\
\text { - Slips at }>1 \text { level } \\
\text { - Transitional vertebrae } \\
\text { - Congenital spondylolisthesis of L5 }\end{array}$ \\
\hline $\begin{array}{l}\text { Jacobsen et } \\
\text { al [3] (2007) }\end{array}$ & $\begin{array}{l}\mathrm{N}=4001 \\
\text { Female: } 62.6 \% \\
\text { Age, range: } 22-93 \text { y }\end{array}$ & $\begin{array}{l}\text { General } \\
\text { - Participants in the Copenhagen Osteoarthritis Study (cohort study } \\
\text { of white, adult subjects from the county of Osterbro in } \\
\text { Copenhagen) } \\
\text { - X-rays available }\end{array}$ & - History of spine surgery for any reason \\
\hline $\begin{array}{l}\text { Imada et al } \\
{[12]} \\
(1995)\end{array}$ & $\begin{array}{l}\text { Cohort: } \\
\mathrm{N}=138 \\
\text { Female: } 100 \% \\
\text { Age, mean: } \\
\text { - Oophorectomy: } 53.8 \text { (range, } \\
\text { 36-70) y } \\
\text { - Non-0ophorectomy: } 53.6 \\
\text { (36-70) y }\end{array}$ & $\begin{array}{l}\text { Case-control: } \\
\text { - Cases were women with low back pain diagnosed with DS, } \\
\text { evaluated by the compass test of Morgan and King on a lateral } \\
\text { x-ray) at the Toyama Medical and Pharmaceutical University } \\
\text { Hospital between } 1981 \text { and } 1991 \\
\text { Controls: } \\
\text { - } 105 \text { patients matched by age, gender, and occupation, chosen at } \\
\text { random from orthopaedic inpatients treated between } 1980 \text { and } \\
1990 \\
\text { Cohort: } \\
\text { - The cohort included } 69 \text { patients who had a bilateral } \\
\text { oophorectomy before menopause and no hormone therapy } \\
\text { between } 1979 \text { and 1989, and a matched comparison group of } 69 \\
\text { non-oophorectomized patients were randomly sampled from } \\
\text { orthopaedic inpatients during the same period }\end{array}$ & None reported \\
\hline
\end{tabular}




\begin{tabular}{|c|c|c|c|}
\hline Author & Demographics $^{\dagger}$ & Inclusion criteria & Exclusion criteria \\
\hline $\begin{array}{l}\text { Grobler et al } \\
{[11]} \\
(1993)\end{array}$ & $\begin{array}{l}\mathrm{N}=51 \\
\text { Female: } 58.8 \% \\
\text { Age, mean: } \\
\text { - Nonpathological: } 41 \text { y } \\
\text { - DS: } 70.0 \text { y }\end{array}$ & $\begin{array}{l}\text { DS: } \\
\text { - DS at L4-5 } \\
\text { - NP: spinal complaints not involving facet joints (determined } \\
\text { radiologically) }\end{array}$ & None reported \\
\hline $\begin{array}{l}\text { Berlemann } \\
\text { et al }[10] \\
(1999)\end{array}$ & $\begin{array}{l}\mathrm{N}=63 \\
\text { Female: } 74.6 \% \\
\text { Age, mean } \pm \text { SD: } \\
\text { - DS: } 69 \pm 10.2 \text { y } \\
\text { - No DS: } 63.2 \pm 8.7 \text { y }\end{array}$ & $\begin{array}{l}\text { General: } \\
\text { - Patients undergoing MRI or CT of lumbar spine for pain }\end{array}$ & $\begin{array}{l}\text { - Developmental anomalies, suspicion of } \\
\text { tumor, infection, or fracture, any signs of } \\
\text { lytic lesions, or scoliotic deformity of }>10^{\circ} \\
\text { - Previous surgery to lower lumbar spine }\end{array}$ \\
\hline $\begin{array}{l}\text { Boden et al } \\
\text { [7] } \\
(1996)\end{array}$ & $\begin{array}{l}\mathrm{N}=94^{\dagger} \\
\text { Female: NR } \\
\text { Age, mean (range): } \\
\text { - DS: } 72 \text { (49-84) y } \\
\text { - Asymptomatic: } 42(20-79) \text { y }\end{array}$ & $\begin{array}{l}\text { General: } \\
\text { - MRI scans of the lumbar spines of: } 67 \text { asymptomatic volunteers, } \\
27 \text { with DS at } L 4-L 5 \text {, and } 46 \text { with disc herniation }\end{array}$ & $\begin{array}{l}\text { Patients with history of low-back pain, } \\
\text { sciatica, claudication, or previous problems } \\
\text { involving the lower limbs were excluded } \\
\text { from controls }\end{array}$ \\
\hline $\begin{array}{l}\text { Love et al } \\
{[14]} \\
(1999)\end{array}$ & $\begin{array}{l}\mathrm{N}=118^{\dagger} \\
\text { Female: } 58.5 \% \\
\text { Age, mean (range): } \\
\text { - Women: } 36.8(24-35) \text { y } \\
\text { - Men: mean } 36.53(26-45) \text { y }\end{array}$ & $\begin{array}{l}\text { General: } \\
\text { - Patients }>55 \text { y who had } x \text {-rays and CT scans before lumbar } \\
\text { decompressive laminectomy who responded to a written request } \\
\text { to send } x \text {-rays and CT scans }\end{array}$ & None reported \\
\hline $\begin{array}{l}\text { Cinotti et al } \\
{[8]} \\
(1997)\end{array}$ & $\begin{array}{l}\mathrm{N}=54 \\
\text { Female: } 55.6 \% \\
\text { Age, mean (range): } \\
\text { - DS: } 62(49-76) \text { y } \\
\text { - Control: } 65(54-75) \text { y }\end{array}$ & $\begin{array}{l}\text { DS: } \\
\text { - L4 with an anterior vertebral slip } \geq 8 \% \text { of the sagittal diameter of } \\
\text { the body of the slipped vertebra, and a decrease of the disc space } \\
\text { below the slipped vertebra }<30 \% \text { compared with the nearest } \\
\text { adjacent normal disc } \\
\text { Controls: } \\
\text { - Patients seen for low back pain and/or leg pain during } 8 \text { mo who } \\
\text { had normal alignment of the lumbar spine }\end{array}$ & None reported \\
\hline $\begin{array}{l}\text { Dai et al [15] } \\
(2001)\end{array}$ & $\begin{array}{l}\mathrm{N}=106 \\
\text { Female: } 60.4 \% \\
\text { Age, range: } \\
\text { - DS: } 42-73 \text { y } \\
\text { - Control: NR (age matched) }\end{array}$ & $\begin{array}{l}\text { DS: } \\
\text { - Symptomatic patient with DS at L4-L5 level with >5\% slip who } \\
\text { were treated at hospital from 1989-1996 } \\
\text { Controls: } \\
\text { - Asymptomatic volunteers }\end{array}$ & $\begin{array}{l}\text { - DS: patients with transitional vertebrae } \\
\text { - Controls: history of low back pain, } \\
\text { sciatica, claudication, previous problems } \\
\text { involving lower limbs }\end{array}$ \\
\hline $\begin{array}{l}\text { Sato et al [16] } \\
(1989)\end{array}$ & $\begin{array}{l}\mathrm{N}=52^{\dagger} \\
\text { Female: } 36.5 \% \\
\text { Age, mean: } \\
\text { - DS: } 59.3 \text { (range, } 40-74) \text { y } \\
\text { - Control: } 36.7 \text { (range, 18-55) y }\end{array}$ & $\begin{array}{l}\text { DS: } \\
\text { - Patients with a forward slip of } L 4 \text { onto } L 5 \text { of }>3 \mathrm{~mm} \text { on lateral } \\
\text { x-rays of the lumbar spine } \\
\text { Controls: } \\
\text { - Patients who had only low back problems but not DS }\end{array}$ & - Patients with transitional vertebrae \\
\hline
\end{tabular}

* DS indicates degenerative spondylolisthesis; MRI, magnetic resonance imaging; CT, computed tomography: and NR, not reported.

† Study design includes additional participants/participant groups; $\mathrm{N}$ reflects only the participants in groups relevant to this topic.

- Two studies used multivariate models to evaluate the association between age and DS. In one, a l-year increase in age was associated with a $9 \%$ increase in risk of DS (odds ratio $[\mathrm{OR}]=1.09 ; 95 \%$ confidence interval [CI]: 1.01-1.17; $P=.019)$ [2]. The other reported a significant association between age and DS only at levels L4 and L5 (OR not reported; $P<.001$ and $P=.02$, respectively) among women, and only at L4 (OR not reported; $P<.001$ ) among men [3].

- In two studies which did not control for confounding, one reported a greater mean age for patients with DS compared with controls (with DS: mean age,
68.2 years; range, $42-93$ years; controls: mean age, 46.8 years; range, $21-69$ years; statistical significance not assessed)[4], and one reported no association between age and DS [5].

- Evidence across three studies suggests the risk of DS is higher for females.

- One study which controlled for confounding reported a 2.4 -fold (95\% CI: 1.1-5.2; $P=.01)$ and 4.0 -fold (95\% CI: $2.5-6.2 ; P<.001)$ increase in risk of DS at L3 and L4, respectively for women. This study also reported a higher prevalence of DS among women (women: 8.3\%; men: $2.7 \%, P$ value not reported) [3]. 
- Two additional studies, which did not control for confounding, also reported a significantly higher prevalence of DS among women (women: 37\%; men: 10\%; $P<.01)$ [5], and reported that men had 95\% lower odds of DS (OR=0.05; 95\% CI: 0.01-0.43; $P=.006)$ [2].

- Evidence across two studies evaluating the association between parity and risk of DS among women was inconsistent.

- One study, which controlled for confounding, reported no association between number of childbirths and DS (ORs not provided) [3]; however, Sanderson and Fraser [6], which did not control for confounding, reported that women who had borne children had a significantly higher incidence of DS than nulliparous women ( $28 \%$ versus $16.7 \% ; P=.043)$.
- The following factors were not associated with DS in two or more studies: back pain $[3,6]$ and prolonged occupational sitting $[2,3]$.

\section{Common radiographic measures evaluated in multiple studies (Table 3)}

- Evidence across six studies evaluating the association between facet joint angle and DS is consistent and suggests the risk of DS increases with increasing facet joint angle.

- Of the six studies, five reported individuals with DS had a greater mean facet joint angle than individuals without DS (for L4-L5: DS: $57.1^{\circ}-102^{\circ}$; controls: $40^{\circ}-89.9^{\circ}$; all $P<.05)[7-9,10,11]$, and in one study, comparing oophorectomized and non-oophorectomized subjects,

Table 2 Summary of sociodemographic, work and activity-related measures evaluated as risk factors for DS in two or more studies.*

\begin{tabular}{|c|c|c|c|c|c|c|}
\hline & & CoE II & & CoE III & & \\
\hline & Summary & $\begin{array}{l}\text { Mariconda et al } \\
\text { [2] } N=120\end{array}$ & $\begin{array}{l}\text { Jacobsen et al [3] } \\
\mathrm{N}=4001\end{array}$ & $\begin{array}{l}\text { Hosoe and Ohmori } \\
\text { [4] } N=250\end{array}$ & $\begin{array}{l}\text { Horikawa et al } \\
{[5] N=528}\end{array}$ & $\begin{array}{l}\text { Sanderson and Fraser } \\
\text { [6] } N=1069\end{array}$ \\
\hline Age & Inconclusive & $\uparrow^{\dagger}$ & $\uparrow^{\dagger}$ & $\uparrow \S$ & NS\| & \\
\hline Gender (female) & $\uparrow$ & $\uparrow^{\dagger}$ & $\uparrow^{\dagger \ddagger}$ & & $\uparrow \pi$ & \\
\hline Parity & Inconclusive & & $\mathrm{NS}^{\dagger}$ & & & $\uparrow \uparrow$ \\
\hline Back pain & NS & & $\mathrm{NS}^{\dagger}$ & & NS & \\
\hline Prolonged occupational sitting & NS & $\mathrm{NS}^{\dagger}$ & NSt & & & \\
\hline
\end{tabular}

* DS indicates degenerative spondylolisthesis; NS, not significant; and upward arrow, increased odds of DS.

$\dagger$ Based on multivariate logistic regression analyses.

₹ Prevalence of DS among women was higher at levels L3, L4, and L5, although the difference between genders for L5 was not significant.

$\S$ Mean age greater in DS cases than control, $P$ value not reported; controls consisted of randomly selected individuals with normal $\mathrm{x}$-rays aside from age-related changes.

$\|$ Based on $t$ test.

"Based on chi-squared test.

Table 3 Summary of radiographic measures evaluated as risk factors for DS in two or more studies.*

\begin{tabular}{|c|c|c|c|c|c|c|c|c|c|}
\hline & & CoE II & CoE III & & & & & & \\
\hline & Summary & $\begin{array}{l}\text { Jacobsen et al } \\
\text { [3] } \\
\mathbf{N}=\mathbf{4 0 0 1}\end{array}$ & $\begin{array}{l}\text { Cinotti et al } \\
{[8]} \\
N=54\end{array}$ & $\begin{array}{l}\text { Imada et al } \\
{[12]} \\
N=210\end{array}$ & $\begin{array}{l}\text { Chen and } \\
\text { Wei [13] } \\
N=132\end{array}$ & $\begin{array}{l}\text { Dai et al } \\
{[15]} \\
N=106\end{array}$ & $\begin{array}{l}\text { Boden et } \\
\text { al [7] } \\
N=94\end{array}$ & $\begin{array}{l}\text { Berlemann } \\
\text { et al [10] } \\
\mathrm{N}=63\end{array}$ & $\begin{array}{l}\text { Grobler } \\
\text { et al [11] } \\
\mathrm{N}=51\end{array}$ \\
\hline Lumbosacral angle & Inconclusive & & NS & $\uparrow \S$ & & & & & \\
\hline Lumbar lordosis & Inconclusive & $\uparrow^{\dagger}$ & & & NS & & & NS & \\
\hline Facet joint tropism & Inconclusive & & NS & & & $\uparrow$ & & & \\
\hline Facet angle & $\uparrow$ & & $\uparrow^{\ddagger}$ & $\uparrow \|$ & & $\uparrow \neq$ & $\uparrow * *$ & $\uparrow^{t+}$ & $\uparrow \S \S$ \\
\hline Pelvic inclination angle & Inconclusive & $\uparrow^{\dagger}$ & & & $\downarrow^{\Uparrow}$ & & & & \\
\hline
\end{tabular}

* DS indicates degenerative spondylolisthesis; NS, not significant; upward arrow, increased odds of DS; and downward arrow, reduced odds of DS.

${ }^{\dagger}$ At $L 4$ and L5, women only.

₹ Facet joint orientation at L3-L4 and L4-L5, not significant for L5-S1.

$\S$ Significant for non-oophorectomized women only.

"l Facets in sagittal plane; significant for both oophorectomized and non-oophorectomized women.

I Sacral inclination angle.

* Facet joint orientation.

** At L3-L4 (right and left), L4-L5 (right and left), and L5-S1 (right only) levels; also the proportion of subjects with sagittal orientation $>45^{\circ}$ ) of both

the left and the right facet.

tt Traverse facet-joint angulation for L4- L5 (right, left and sum), L4 and S1.

$\S \S L 4-L 5$. 
a greater proportion of DS than control subjects had facets in the sagittal plane (oophorectomied: $60.9 \%$ versus $10.2 \%$, respectively; non-oophorectomized: $54.4 \%$ versus $24.2 \%$, respectively; $P<.01$ for both) [10, 11]. None of the studies controlled for confounding.

- Evidence across two studies evaluating the association between lumbosacral angle and DS was inconsistent.

- Imada et al [12] reported a significant increase in the lumbosacral angle among non-oophorectomized individuals with DS compared with controls; however, there was no association between lumbosacral angle and DS among oophorectomized individuals, and Cinotti et al [8] reported no association between lumbosacral angle and DS.

- Evidence across three studies evaluating the association between lumbar lordosis angle and DS was inconsistent.

- In one study, which controlled for confounding, lumbar lordosis angles were significantly greater among women with DS compared with women without DS; however, there was no association between lumbar lordosis angle and DS among men [3].

- Two studies [10, 13] report no differences in the mean lumbar lordosis angle between individuals with DS and controls.

- Evidence across two studies evaluating the association between facet joint tropism and DS was inconsistent.

- In one study, patients with DS had significantly greater facet joint tropism than controls $\left(12.9^{\circ} \pm 9.54^{\circ}\right.$ versus $1.6^{\circ} \pm 7.25^{\circ}$, respectively; $P<.05$ ) [9]; however, Cinotti et al [8] reported no difference in the proportion of DS and control patients with a facet joint tropism $(P>.05)$.

- Evidence across two studies evaluating the association between pelvic inclination angle and DS was inconsistent.

- In one study [3], which controlled for confounding, women with DS had significantly greater pelvic inclination angle at L4 and L5 (means not reported by case status, and ORs not reported; $P=.009$ and $P=.007$, respectively); however, there was no association between pelvic inclination angle and DS among men.

- In another study [13], which also controlled for confounding, patients with DS had a significantly lower sacral inclination angle (pelvic inclination angle) than controls $\left(36.42^{\circ} \pm 10.05^{\circ}\right.$ versus $41.91^{\circ} \pm 9.71^{\circ}$, respectively; $P<.01)$.

\section{Prognostic factors evaluated in single studies (Table 4)}

- In single studies, the following characteristics were associated with DS: any and bilateral oophorectomy, height and BMI (women only), heavy workload, practice of sport and lifetime work exposure and prolonged occupational standing (both associated with lower rate of DS) $[2,3,12]$.
- No association between the following characteristics and DS: unilateral oophorectomy, weight, BMI and height (men), and job workload category, manual material handling, load weight, professional vehicle driving, previous occupational trauma, occupational psychosocial risk factors, age at menopause, standing, walking and no daily repetitive lifting, and years lifting $50-250 \times 20 \mathrm{~kg} / 0-100 \times 50 \mathrm{~kg}$ or $20-250 \times$ $20 \mathrm{~kg} / 10-100 \times 50 \mathrm{~kg}$ daily $[2,3,12]$.

Table 4 Summary of sociodemographic, work, and activity-related measures evaluated as risk factors for DS in one study.*

\begin{tabular}{|c|c|c|c|}
\hline & $\begin{array}{l}\text { Mariconda } \\
\text { et al }[2]^{\dagger} \\
\mathrm{N}=120\end{array}$ & $\begin{array}{l}\text { Jacobsen } \\
\text { et al [12]‡ } \\
\mathrm{N}=\mathbf{4 0 0 1}\end{array}$ & $\begin{array}{l}\text { Imada et } \\
\text { al [11] } \\
N=210\end{array}$ \\
\hline $\begin{array}{l}\text { Any oophorectomy } \\
\text { - Bilateral } \\
\text { - Unilateral }\end{array}$ & & & $\begin{array}{l}\uparrow \\
\uparrow \\
N S\end{array}$ \\
\hline $\begin{array}{l}\text { BMI } \\
\text { - Women } \\
\text { - Men }\end{array}$ & & $\begin{array}{l}\uparrow \\
\text { NS }\end{array}$ & \\
\hline $\begin{array}{l}\text { Weight } \\
\text { - Women } \\
\text { - Men }\end{array}$ & & $\begin{array}{l}\text { NS } \\
\text { NS }\end{array}$ & \\
\hline $\begin{array}{l}\text { Height } \\
\text { - Women } \\
\text { - Men }\end{array}$ & & $\begin{array}{l}\uparrow \\
\text { NS }\end{array}$ & \\
\hline Age at menopause & & NS & \\
\hline Smoking & & NS & \\
\hline Lifetime working exposure & $\downarrow$ & & \\
\hline Job workload category & NS & & \\
\hline Heavy workload & $\uparrow$ & & \\
\hline Manual material handling & NS & & \\
\hline Load weight & NS & & \\
\hline Prolonged occupational standing & $\downarrow$ & & \\
\hline Professional vehicle driving & NS & & \\
\hline Previous occupational trauma & NS & & \\
\hline Occupational psychosocial risk factors & NS & & \\
\hline Practice of sport & $\uparrow$ & & \\
\hline $\begin{array}{l}\text { Standing, walking, no daily repetitive } \\
\text { lifting }\end{array}$ & & NS & \\
\hline $\begin{array}{l}\text { Years lifting } 50-250 \times 20 \mathrm{~kg} \text { or } \\
20-100 \times 50 \mathrm{~kg} \text { daily }\end{array}$ & & NS & \\
\hline $\begin{array}{l}\text { Years lifting } 20-250 \times 20 \mathrm{~kg} \text { or } \\
10-100 \times 50 \mathrm{~kg} \text { daily }\end{array}$ & & NS & \\
\hline
\end{tabular}

* DS indicates degenerative spondylolisthesis; NS, not significant; upward arrow, increased odds of DS; and downward arrow, reduced odds of DS.

$\dagger$ Based on multivariate logistic regression analyses (age, gender).

‡Associations of body mass index, weight, height age at menopause, and smoking status with DS were assessed by multivariate logistic regression models stratified by gender.

$\S$ Based on McNemars test. 
Radiographic measures evaluated in single studies (Table 5)

- The following radiographic measures were associated with DS: traverse process length, mean sagittal translation, and iliac crest height in single studies $[4,8,13]$.

- No association between the following radiographic measures and DS: traverse process width and mean angular motion was reported in single studies [8, 13].

Table 5 Summary of radiographic measures evaluated as risk factors for DS in one study.*

\begin{tabular}{llll}
\hline & $\begin{array}{l}\text { Chen et } \\
\text { al [13] } \\
\mathbf{N = 1 3 2}\end{array}$ & $\begin{array}{l}\text { Cinotti et } \\
\text { al [8] } \\
\mathbf{N = 5 4}\end{array}$ & $\begin{array}{l}\text { Hosoe and } \\
\text { Ohmori [4] } \\
\mathbf{N = 2 5 0}\end{array}$ \\
\hline Traverse process length & $\uparrow^{\dagger}$ & & \\
\hline Traverse process width & $\mathrm{NS}^{\dagger}$ & & \\
\hline Mean angular motion & & $\mathrm{NS}^{\ddagger}$ & \\
\hline Mean sagittal translation & & $\uparrow^{\S}$ & \\
\hline lliac crest height & & & $\uparrow$ \\
\hline
\end{tabular}

* DS indicates degenerative spondylolisthesis; NS, not significant; and upward arrow, increased odds of DS.

$\dagger$ L5.

₹ At L4-L5.

$\S$ At L4-L5.

Fig 2 The facet angle of a normal L4-5 lumbar segment.

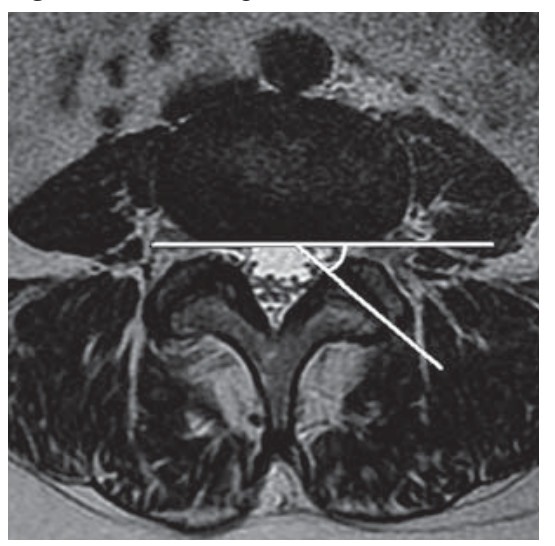

Fig 3 Increased facet angle in an L4-5 lumbar segment with degenerative spondylolisthesis.

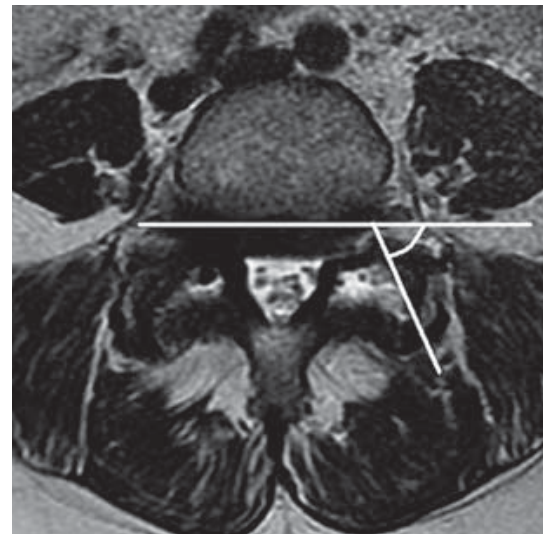

\section{DISCUSSION}

- The primary limitation of the evidence evaluating risk factors for DS is the poor quality of studies. Twelve of 14 studies were CoE III, and only two were CoE II. Most studies (all CoE III studies) did not attempt to control for confounding (Table 6).

- In addition, comparison of results across studies is complicated due to the following differences in the selected study populations:

- The selection of DS cases differed substantially across studies, with some studies restricting selection to patients with DS at L4-L5, and others including any DS regardless of the level.

- One study included patients who were undergoing surgery, which may be likely to include more severe cases of DS [14].

- Some studies selected only symptomatic DS subjects $[2,10,12-15]$ and other studies do not report whether DS subjects were symptomatic $[4,5,7,8,11,16]$.

- One study selected older subjects [5], and some selected younger subjects [13], and in two studies, there were substantial differences in age between DS cases and controls [7, 16].

- Most studies did not report whether cases were restricted to "degenerative forms" of spondylolisthesis $[2,3,5,7,8,10-12,14-16]$.

- Some studies presented all analyses stratified by subpopulation (ie, oophorectomy status, gender, level of DS) $[3,7,8,10-12]$.

- Our objective was to critically appraise and summarize evidence on risk factors for DS. To this aim, we accomplished our goal. Typically, the aim of such an exhaustive review is to identify risk factors that, from a clinical perspective, might be influenced by the clinician. For example, if the risk factor is environmental in nature and modifiable, steps could be formulated to decrease the risk, and ultimately influence the incidence or severity of the disease. If the risk factor is anatomical, it could be amendable to closer observation, or even surgical correction to prevent the clinical symptoms that accompany pathological progression.

- In our systematic review, we found consistent evidence to suggest that the risk of DS increases with increasing age and is greater for females and people with a greater facet joint angle. Female gender and greater facet joint angle were consistently associated with an increased risk of DS across multiple studies. Increased sagittalization of the facet joints limits the ability to resist forward displacement, and surgeons have recognized this anatomical variant and its association with hypermobility and the development of DS (Figs $\mathbf{2}$ and $\mathbf{3}$ ). This anatomical variant, although easily identifiable, is not amendable to modification. Female gender has also 


\section{EVIDENCE SUMMARY}

Table 6 What is the association between risk factors reported in more than one study and degenerative spondylolisthesis?

\begin{tabular}{|c|c|c|c|c|c|}
\hline Risk factors & Strength & lence & & & Conclusions/comments \\
\hline 1. Age & Very low & Low & Moderate & High & Inconclusive: Two higher-quality (CoE II) studies and one \\
\hline 2. Gender & Very low & Low & Moderate & High & $\begin{array}{l}\text { Consistent evidence across three studies (one } \mathrm{CoE} I I \text { and two } \mathrm{CoE} \\
\text { III) reporting an increased risk of DS for females }\end{array}$ \\
\hline 3. Parity & Very low & Low & Moderate & High & Inconclusive: One higher-quality (CoE II) study reported no \\
\hline 4. Back pain & Very low & Low & Moderate & High & Consistent evidence across one higher-quality (CoE II) and one \\
\hline 5. Prolonged occupational & Very low & Low & Moderate & High & Consistent evidence across two lower-quality (CoE III) studies \\
\hline 6. Facet angle & Very low & Low & Moderate & High & Consistent evidence across six lower-quality (CoE III) studies which \\
\hline 7. Lumbosacral angle & Very low & Low & Moderate & High & Inconclusive: One lower-quality (CoE III) study reported no \\
\hline 8. Lumbar lordosis & Very low & Low & Moderate & High & Inconclusive: One higher-quality (CoE II) study reported an \\
\hline 9. Facet joint tropism & Very low & Low & Moderate & High & Inconclusive: One lower-quality (CoE III) study reported no \\
\hline 10. Pelvic inclination angle & Very low & Low & Moderate & High & Inconclusive: One higher-quality (CoE II) study reported no \\
\hline
\end{tabular}


been long recognized as a risk factor and confirmed in our systematic review. However, the explanation for this gender-specific risk has been largely inconclusive. It is likely that changes in estrogen production and the resultant effect on soft tissues play a role, but to what extent is unknown.

- The ideal method for studying the risk factors associated with the development of DS includes a prospective analysis of a large group of patients from adolescence through adulthood, making periodic assessment of all potential risk factors including anatomical parameters via advanced imaging, hormonal levels, occupational exposures, and in the future, possibly genetic analysis, accounting for confounding variables. Although ideal, it would be costly, time consuming, and probably not feasible particularly since it appears that the identifiable risk factors are not amendable to modification.

\section{REFERENCES}

1. Junghanns H (1930) Spondylolisthesis ohne spalt in zwischengelenstuck. Arch Orthop Unfallchir; 29:118-127. German.

2. Mariconda M, Galasso O, Imbimbo L, et al (2007) Relationship between alterations of the lumbar spine, visualized with magnetic resonance imaging, and occupational variables. Eur Spine J; 16(2):255-266.

3. Jacobsen $\mathbf{S}$, Sonne-Holm $\mathbf{S}$, Rovsing $H$, et al (2007) Degenerative lumbar spondylolisthesis: an epidemiological perspective: the Copenhagen Osteoarthritis Study. Spine (Phila Pa 1976); 32(1):120-125.

4. Hosoe H, Ohmori K (2008) Degenerative lumbosacral spondylolisthesis: possible factors which predispose the fifth lumbar vertebra to slip. J Bone Joint Surg Br; 90(3):356-359.

5. Horikawa K, Kasai Y, Yamakawa $T$, et al (2006) Prevalence of osteoarthritis, osteoporotic vertebral fractures, and spondylolisthesis among the elderly in a Japanese village. J Orthop Surg (Hong Kong); 14(1):9-12.
6. Sanderson PL, Fraser RD (1996) The influence of pregnancy on the development of degenerative spondylolisthesis. $J$ Bone Joint Surg $B r$; 78(6):951-954.

7. Boden SD, Riew KD, Yamaguchi $K$, et al (1996) Orientation of the lumbar facet joints: association with degenerative disc disease. J Bone Joint Surg Am; 78(3):403-411.

8. Cinotti G, Postacchini F, Fassari F, et al (1997) Predisposing factors in degenerative spondylolisthesis: a radiographic and CT study. Int Orthop; 21(5):337-342.

9. Dai F, Belfer I, Schwartz CE, et al (2010) Association of catechol-O-methyltransferase genetic variants with outcome in patients undergoing surgical treatment for lumbar degenerative disc disease. Spine J; 10(11):949-957.

10. Berlemann U, Jeszenszky DJ, Buhler DW, et al (1999) The role of lumbar lordosis, vertebral end-plate inclination, disc height, and facet orientation in degenerative spondylolisthesis. J Spinal Disord; 12(1):68-73.

11. Grobler LJ, Robertson PA, Novotny JE, et al (1993) Etiology of spondylolisthesis: assessment of the role played by lumbar facet joint morphology. Spine (Phila Pa 1976); 18(1):80-91.

12. Imada K, Matsui H, Tsuji H (1995) Oophorectomy predisposes to degenerative spondylolisthesis. J Bone Joint Surg Br; 77(1):126-130.

13. Chen IR, Wei TS (2009) Disc height and lumbar index as independent predictors of degenerative spondylolisthesis in middle-aged women with low back pain. Spine (Phila Pa 1976); 34(13):1402-1409.

14. Love TW, Fagan AB, Fraser RD (1999) Degenerative spondylolisthesis: developmental or acquired? J Bone Joint Surg Br; 81(4):670-674.

15. Dai LY (2001) Orientation and tropism of lumbar facet joints in degenerative spondylolisthesis. Int Orthop; 25(1):40-42.

16. Sato K, Wakamatsu E, Yoshizumi A, et al (1989) The configuration of the laminas and facet joints in degenerative spondylolisthesis: a clinicoradiologic study. Spine (Phila Pa 1976); 14(11):1265-1271.

17. Wright JG, Swiontkowski MF, Heckman JD (2003) Introducing levels of evidence to the journal. J Bone Joint Surg Am; 85-A(1):1-3.

18. Atkins D, Best D, Briss PA, et al (2004) Grading quality of evidence and strength of recommendations. BMJ; 328(7454):1490.

19. West S, King V, Carey TS, et al (2002) Systems to Rate the Strength of Scientific Evidence. Evidence Report/Technology Assessment No. 47 (Prepared by the Research Triangle Institute-University of North Carolina Evidencebased Practice Center, Contract No. 290-970011). Rockville, MD: US Agency for Healthcare Research and Quality. 


\section{EDITORIAL PERSPECTIVE}

The reviewers uniformly applauded DeVine and colleagues for their review and had little objections or criticisms. The age variable as risk factor for degenerative spondylolisthesis (DS) received some attention. It seemed self-evident considering that disc degeneration would be strongly related to age, and DS would then be one of the potential consequences of disc degeneration. It would be interesting to know whether or not age is an independent factor? For clarification an analysis of people in the same disc degeneration stage but with different age would be useful. This analysis is not possible without further study of source data, something that was not available to the authors but that could be done with future data collections.

The frequently suspected association of female gender and DS was also clearly demonstrated. It is possible that this link is due to the hormonal background and the consequential differences in soft-tissue properties in genders. However, a way to differentiate causation would be to study the association (or its lack) between female gender and greater facet joint angle. A similar discussion could be had surrounding the incidence of facet joint tropism (asymmetric facet joint angulation), which has received only scant consideration in studies dealing with predisposing risk factors of spondylolisthesis (Fig 4).

There are other biomechanical factors to consider. How many patients in these studies presented had an abnormal motion segment at L5/S1 with reduced motion due to advanced disc degeneration or segmentation anomaly at L5-S1, such as Bertolotti's syndrome (abnormal bridging of $L 5$ transverse process with sacral ala-found unilaterally or bilaterally)? Reduced motion at L5-S1 would seemingly increase the biomechanical forces exerted upon L4-5, thus leading to an earlier decay of that segment. Again the health and functionality of the L5-SI disc as a confounding variable in the development of premature degeneration of the L4-5 motion segment has been virtually ignored in the literature to date.

Finally, there are other connective tissue-related risk factors aside from hormonal factors, which seemingly would warrant assessment as to causation. Connective tissue diseases (such as rheumatoid arthritis) and their antiinflammatory treatments clearly may have an association with DS but have not been studied, as this review shows.
Finally, the clinical diagnosis of DS as a distinct clinical pathoentity is receiving a good deal more attention with an aging population requiring some form of treatment to remain functional and decrease pain. There remains controversy surrounding its ideal treatment starting with the question how far to take nonoperative care and when to intervene surgically. Within surgical techniques in DS treatment, questions persist as to the role of decompression alone, decompression with fusion, or some type of motion preserving implant. With an increasing understanding of causation and sharpened analytical skills to understand this pathoentity better, we may advance in our ability to not only treat symptomatic patients but perhaps also prevent progression in earlier stages.

For those interested in learning more about confounding factors in population analyses, see "Assessing bias: the importance of considering confounding," pages 9-12, in the February 2012 issue of EBSJ.

Fig 4 Example of facet tropism-the right-sided joint angel measure $16^{\circ}$, the left over $40^{\circ}$. It is possible that such asymmetry leads to premature wear of the facet joints and may predispose to degenerative spondylolisthesis.

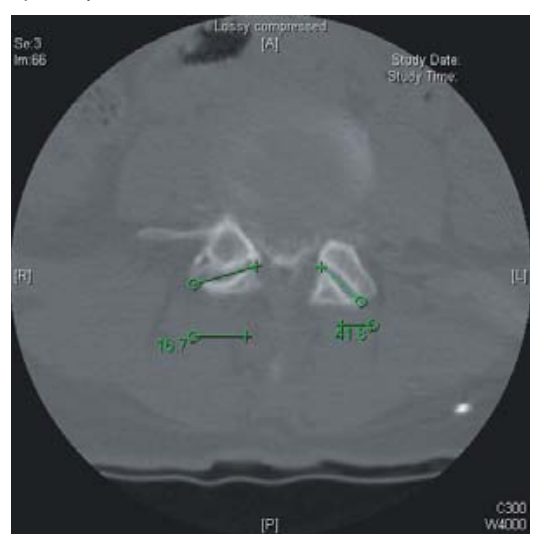

